\title{
NF- $K B$ signaling and its relevance to the treatment of mantle cell lymphoma
}

\author{
Swathi Balaji, Makhdum Ahmed, Elizabeth Lorence, Fangfang Yan, Krystle Nomie and Michael Wang*
}

\begin{abstract}
Mantle cell lymphoma is an aggressive subtype of non-Hodgkin B cell lymphoma that is characterized by a poor prognosis determined by Ki67 and Mantle Cell International Prognostic Index scores, but it is becoming increasingly treatable. The majority of patients, especially if young, achieve a progression-free survival of at least 5 years. Mantle cell lymphoma can initially be treated with an anti-CD20 antibody in combination with a chemotherapy backbone, such as VR-CAP (the anti-CD20 monoclonal antibody rituximab administered with cyclophosphamide, doxorubicin, and prednisone) or R-CHOP (the anti-CD20 monoclonal antibody rituximab administered with cyclophosphamide, doxorubicin, vincristine, and prednisone). While initial treatment can facilitate recovery and complete remission in a few patients, many patients experience relapsed or refractory mantle cell lymphoma within 2 to 3 years after initial treatment. Targeted agents such as ibrutinib, an inhibitor of Bruton's tyrosine kinase, which has been approved only in the relapsed setting, can be used to treat patients with relapsed or refractory mantle cell lymphoma. However, mantle cell lymphoma cells often acquire resistance to such targeted agents and continue to survive by activating alternate signaling pathways such as the PI3K-Akt pathway or the NF-KB pathways.

NF- $K B$ is a transcription factor family that regulates the growth and survival of B cells; mantle cell lymphoma cells depend on NF-KB signaling for continued growth and proliferation. The NF-KB signaling pathways are categorized into canonical and non-canonical types, wherein the canonical pathway prompts inflammatory responses, immune regulation, and cell proliferation, while the non-canonical leads to B cell maturation and lymphoid organogenesis. Since these pathways upregulate survival genes and tumor-promoting cytokines, they can be activated to overcome the inhibitory effects of targeted agents, thereby having profound effects on tumorigenesis. The NF-KB pathways are also highly targetable in that they are interconnected with numerous other pathways, including B cell receptor signaling, $\mathrm{PIBK} / \mathrm{Akt} / \mathrm{mTOR}$ signaling, and toll-like receptor signaling pathways. Additionally, elements of the non-canonical NF- $k B$ pathway, such as NF-kB-inducing kinase, can be targeted to overcome resistance to targeting of the canonical NF- $k B$ pathway.

Targeting the molecular mechanisms of the NF-kB pathways can facilitate the development of novel agents to treat malignancies and overcome drug resistance in patients with relapsed or refractory mantle cell lymphoma.
\end{abstract}

Keywords: NF-kB, Mantle cell lymphoma, Canonical pathway, Non-canonical pathway

\section{Background}

Mantle cell lymphoma (MCL) is an aggressive B cell lymphoma with one of the worst prognoses of all non-Hodgkin lymphomas. MCL cells are marked by a $t(11: 14)$ chromosomal translocation and overexpression of cyclin D1. Although MCL is incurable to date, impressive response rates have been achieved via targeted agents,

\footnotetext{
* Correspondence: miwang@mdanderson.org

Department of Lymphoma/Myeloma, University of Texas MD Anderson

Cancer Center, 1515 Holcombe Blvd. Unit 0429, Houston, TX 77030-4009, USA
}

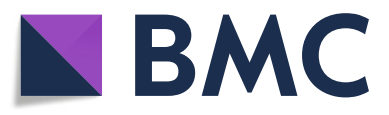

(c) The Author(s). 2018 Open Access This article is distributed under the terms of the Creative Commons Attribution 4.0 International License (http://creativecommons.org/licenses/by/4.0/), which permits unrestricted use, distribution, and reproduction in any medium, provided you give appropriate credit to the original author(s) and the source, provide a link to the Creative Commons license, and indicate if changes were made. The Creative Commons Public Domain Dedication waiver (http://creativecommons.org/publicdomain/zero/1.0/) applies to the data made available in this article, unless otherwise stated. such as ibrutinib, a Bruton's tyrosine kinase (BTK) inhibitor. Unfortunately, MCL cells inevitably develop resistance to ibrutinib, making it difficult to treat. While some MCL cell lines are highly sensitive to the B cell receptor (BCR) signaling inhibitors ibrutinib and sotrastaurin, other MCL cell lines, including Z-138 and Maver-1, are insensitive and demonstrate activation of the non-canonical NF- $k \mathrm{~B}$ pathway, instead of the canonical pathway [1]. This finding suggests that patients with drug-resistant MCL may benefit from alternate treatment approaches, particularly those that are independent of the BCR signaling pathway.

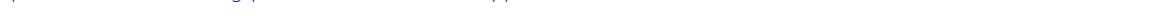


The nuclear factor kappa-light-chain enhancer of activated $\mathrm{B}$ cells $(\mathrm{NF}-\kappa \mathrm{B})$ is a transcription factor family that regulates the expression of growth factors, cytokines, chemokines, adhesion molecules, and apoptosis inhibitors [2]. NF- $\kappa \mathrm{B}$ is known for its regulatory role in inflammatory responses and other pathological processes, including cell differentiation and survival. The NF- $\kappa \mathrm{B}$ family has five monomers: RelA, RelB, c-Rel, p50, and 52 , which combine to form up to 15 different NF- $\kappa \mathrm{B}$ complexes, of which p50-p65 (canonical) and p52-RelB (non-canonical) are paradigmatic.

There are several pathways for NF- $\kappa \mathrm{B}$ activation, but the two primary pathways are the canonical and non-canonical pathways. The canonical pathway is triggered by toll-like microbial pattern recognition receptors (TLRs) and pro-inflammatory cytokines such as tumor necrosis factor alpha (TNF $\alpha$ ) and interleukin-1 (IL-1), which leads to the activation of RelA- or cRel-containing complexes [3]. The non-canonical pathway is activated by TNF (tumor necrosis factor) family cytokines, including lymphotoxin $\beta$ (TNFSF3), CD40 ligand (CD40L and TNFSF5), and $B$ cell-activating factor (BAFF and TNFSF13B). The canonical pathway has downstream effects including inflammatory responses, immune regulation, and cell proliferation, while the non-canonical pathway's downstream effects lead to B cell maturation and lymphoid organogenesis. An understanding of NF- $\kappa$ B pathway mechanisms in MCL tumorigenesis will facilitate the development of more effective therapeutic agents that suit different patient populations (Table 1).

\section{Main text}

\section{The canonical pathway}

The p50-p65 heterodimer is a transcription factor of the NF-kB family that is bound to and inhibited by ІкB. Activation of the canonical pathway leads to proteasomal degradation of ІкB, leading to downstream gene expression.

The p50-p65 heterodimer is initially bound to $\mathrm{I} \mathrm{kB}$, which prevents the heterodimer from entering the nucleus and enabling gene expression. Lipopolysaccharides (LPSs), tumor necrosis factor alpha (TNF- $\alpha$ ), and interleukin-1 (IL-1) activate toll-like receptors (TLR), tumor necrosis factor receptors (TNFR), and interleukin-1 receptors (IL-1R), respectively. Activation of these receptors initiates adapter protein and signaling kinase responses, leading to activation of the IKB kinase (IKK) complex. The IKK complex consists of IKK $\alpha$, IKK $\beta$, and two IKK $\gamma$ (NEMO) kinases, which phosphorylate $\mathrm{I} \kappa \mathrm{B}$ on the serine residues S32 and S36, leading to the poly-ubiquitination and proteasomal degradation of $\mathrm{I} \kappa \mathrm{B}$ [4]. This allows the $\mathrm{p} 50$ and p65-RelA heterodimer (a complex from the NF- $\kappa$ B family) to be released into the nucleus to induce gene expression.

\section{Interactions with signaling pathways that coordinate with the NF-KB canonical pathway}

BCR signaling The downstream effects of antigen-mediated BCR signaling lead to activation of BTK and eventually the IKK complex, which leads to gene expression via the canonical pathway. The BCR signaling pathway is mediated by receptor tyrosine kinase-mediated signal transduction. The B cell receptor consists of the immunoglobulins IgM, IgD, Ig-alpha, and Ig-beta, which are expressed by $\mathrm{B}$ cells and bound to CD79a/CD79b. When antigens bind to these immunoglobulins, tyrosine kinases including LYN, FYN, and B lymphocyte tyrosine kinase (BLK) phosphorylate the dual-tyrosine containing immunoreceptor tyrosine-based activation motifs (ITAMs) in the cytoplasmic tails of Ig-alpha and Ig-beta [5]. Spleen tyrosine kinase (SYK) binds to the phosphorylated ITAMs and becomes activated, then mediating tyrosine phosphorylation of proteins including $B$ cell linker (BLNK) and B cell adaptor for phosphoinositide 3-kinase (BCAP) (Fig. 1) [6]. Upstream Src family kinases including BLK and LYN, which phosphorylates CD19, activate Bruton's tyrosine kinase (BTK) [7]. BTK phosphorylates and activates 1-phosphatidylinositol-4,5-bisphosphate phosphodiesterase gamma-2 (PLC $\gamma 2$ ), which leads to downstream signaling involving $\mathrm{Ca}^{2+}$ release and phosphorylation of CARMA/CARD11 by protein kinase C beta (PKC $\beta)$ [8]. CARMA/CARD11 associates with B cell lymphoma/ leukemia 10 protein (BCL10) and mucosa-associated lymphoid tissue lymphoma translocation protein 1 (MALT1), forming the CARD11-BCL10-MALT1 (CBM) signalosome complex [9]. Once the CBM complex is formed, the IKK complex is activated, leading to p50 and p65-RelA translocation to the nucleus via the canonical NF- $\kappa$ B pathway.

Molecular mechanisms involved in canonical BCR-driven signaling have profound effects on tumorigenesis. For instance, the dysregulation of NF- $\mathrm{kB}$ in chronic lymphocytic leukemia (CLL) cells causes overexpression of anti-apoptotic genes; CLL cells have elevated SYK, LYN, and BTK expression and elevated PI3K activity. Ligation of the $B$ cell receptor in vitro has been shown to induce more NF- $\mathrm{KB}$ DNA-binding activity in the nucleus of CLL cells, thereby increasing cellular survival [10]. Survival of diffuse large B cell lymphoma (DLBCL) cells and other lymphoma cells similarly depends on CARMA1/CARD11 and NF- $\kappa$ B signaling $[11,12]$. Two cell lines of activated $B$ cell-like diffuse large $\mathrm{B}$ cell lymphoma (ABC-DLBCL) had high levels of NF- $\mathrm{B}$ D DNA-binding activity in the nucleus, constitutive IKK activity, and rapid IкB degradation that were not observed in germinal center B cell-like diffuse large B cell lymphoma (GCB-DLBCL) [11], demonstrating the 
Table 1 Various agents targeting the NF-KB pathway

\begin{tabular}{|c|c|c|c|}
\hline Agent name & Agent mechanism & $\begin{array}{l}\text { Relevant target } \\
\text { pathway }\end{array}$ & Tested in MCL cells/patients? \\
\hline Ibrutinib & Bruton's tyrosine kinase (BTK) inhibitor & $\begin{array}{l}\text { Canonical NF-KB } \\
\text { pathway; BCR } \\
\text { signaling }\end{array}$ & $\begin{array}{l}\text { Yes-tested in vitro, in vivo, in clinical trials; approved } \\
\text { by the FDA; } 68 \% \text { overall response rate in MCL patients [54] }\end{array}$ \\
\hline Acalabrutinib & $\begin{array}{l}\text { Second-generation Bruton's tyrosine } \\
\text { kinase (BTK) inhibitor }\end{array}$ & $\begin{array}{l}\text { Canonical NF-KB } \\
\text { pathway; BCR } \\
\text { signaling }\end{array}$ & $\begin{array}{l}\text { Yes - tested in relapsed or refractory mantle cell } \\
\text { lymphoma in a single-arm, multicenter, phase } 2 \text { trial; } \\
81 \% \text { overall response and } 40 \% \text { complete response } \\
\text { for } 124 \text { patients at a median follow-up of } 15.2 \text { months [55] }\end{array}$ \\
\hline Bortezomib & $\begin{array}{l}\text { Proteasome inhibitor } \rightarrow \text { prevents degradation } \\
\text { of ubiquitinated IKB; induces cell death via } \\
\text { oxidative and ER stress } \rightarrow \text { NOXA upregulation } \\
\text { (NF-kB independent) }\end{array}$ & $\begin{array}{l}\text { Canonical NF-KB } \\
\text { pathway }\end{array}$ & $\begin{array}{l}\text { Yes-tested in vitro, in vivo, and in clinical trials; } \\
\text { approved by the FDA; } 33 \% \text { overall response rate } \\
\text { in R/R MCL patients [56] }\end{array}$ \\
\hline Rituximab & $\begin{array}{l}\text { Chimeric anti-CD20 antibody; downregulates } \\
\text { BCl-x(L) expression; decreases the phosphorylation } \\
\text { of NF-KB-inducing kinase, IKB kinase, and IKBa; } \\
\text { diminishes IKK kinase activity; and decreases } \\
\text { NF-KB DNA-binding activity }\end{array}$ & $\begin{array}{l}\text { Canonical and } \\
\text { non-canonical } \\
\text { NF-kB pathways }\end{array}$ & $\begin{array}{l}\text { Yes-widely used in clinical treatment of patients with } \\
\text { non-Hodgkin lymphoma }(\mathrm{NHL}) \text {; also tested in vitro in } \\
\mathrm{CD} 20(+) \text { drug-resistant cell lines Ramos }(\mathrm{BCl}-2(-) / \mathrm{BCl}-\mathrm{x}(\mathrm{L}) \\
(+)) \text { and Daudi }(\mathrm{BCl}-2(+) / \mathrm{BCl}-\mathrm{x}(\mathrm{L})(+))[57]\end{array}$ \\
\hline Lenalidomide & $\begin{array}{l}\text { Downregulates pro-inflammatory cytokines, } \\
\text { such as TNF-a, IL-1, and IL-6 }\end{array}$ & $\begin{array}{l}\text { Canonical NF-KB } \\
\text { pathway }\end{array}$ & $\begin{array}{l}\text { Yes_approved for the treatment of patients with MCL } \\
\text { whose disease has relapsed or progressed after two } \\
\text { prior therapies, one of which included bortezomib }\end{array}$ \\
\hline Idelalisib & PI3KS inhibitor & $\begin{array}{l}\text { Cross-talk between } \\
\text { NF-kB and PI3KJAkt } \\
\text { pathways }\end{array}$ & $\begin{array}{l}\text { Yes_-phase I study in } 2014 \text { for treatment of relapsed/ } \\
\text { refractory MCL patients, overall response rate of } 40 \% \\
\text { ( } 16 / 40 \text { patients) [58]; phase I study in } 2014 \text { for treatment } \\
\text { of patients with indolent non-Hodgkin lymphoma (NHL), } \\
\text { overall response rate of } 47 \% \text { (30/64 patients) [44] }\end{array}$ \\
\hline Auranofin & $\begin{array}{l}\text { Inhibits homodimerization of toll-like receptor } \\
4 \text { (TLR4), thereby suppressing TLR-mediated } \\
\text { activation of NF-KB [59] }\end{array}$ & $\begin{array}{l}\text { Canonical NF-KB } \\
\text { pathway; TLR } \\
\text { signaling }\end{array}$ & $\begin{array}{l}\text { Phase I/II clinical trial at University of Kansas Medical } \\
\text { Center to evaluate safety and efficacy of auranofin in } \\
\text { chronic lymphocytic leukemia (CLL), small lymphocytic } \\
\text { lymphoma (SLL), and/or prolymphocytic lymphoma } \\
\text { (PLL) patients (clinicaltrials.gov) }\end{array}$ \\
\hline Duvelisib & PI3K inhibitor & $\begin{array}{l}\text { Cross-talk between } \\
\text { NF-kB and PI3K/Akt } \\
\text { pathways }\end{array}$ & $\begin{array}{l}\text { Yes-tested in vitro and in patient-derived xenograft } \\
\text { studies; inhibited MCL growth in vitro and in PDX mice [45] }\end{array}$ \\
\hline ACP-319 & PI3K inhibitor & $\begin{array}{l}\text { Cross-talk between } \\
\text { NF-kB and PI3K/Akt } \\
\text { pathways }\end{array}$ & $\begin{array}{l}\text { Yes_-undergoing phase } 1 / 2 \text { clinical trial in combination } \\
\text { with ACP-196 in subjects with B cell malignancies, } \\
\text { including MCL (no study results posted yet—clinicaltrials.gov) }\end{array}$ \\
\hline $\begin{array}{l}\text { AM-0216 and } \\
\text { AM-0561 }\end{array}$ & NIK inhibitors & $\begin{array}{l}\text { Non-canonical } \\
\text { NF-kB pathway }\end{array}$ & $\begin{array}{l}\text { Tested in vitro in multiple myeloma cells; was not } \\
\text { possible to do in vivo studies due to poor } \\
\text { pharmacokinetic properties, but drug combination } \\
\text { may be more promising [35] }\end{array}$ \\
\hline ASN002 & Syk/jak inhibitor & $\begin{array}{l}\text { Canonical NF-KB } \\
\text { pathway; BCR } \\
\text { signaling }\end{array}$ & $\begin{array}{l}\text { Showed anti-proliferative activity in many cell lines and } \\
\text { inhibited tumor growth in a multiple myeloma } \\
\text { xenograft model; phase I/II ongoing clinical study [60] }\end{array}$ \\
\hline CUDC-907 & PI3K/histone deacetylase (HDAC) inhibitor & $\begin{array}{l}\text { Canonical NF- } k B \\
\text { pathway; BCR and } \\
\text { TCR signaling }\end{array}$ & $\begin{array}{l}\text { Yes_inhibits tumor growth of ibrutinib-resistant MCL } \\
\text { in vitro and in PDX model [61]; phase I/II trial for } \\
\text { relapsed or refractory lymphoma or multiple myeloma } \\
\text { (clinicaltrials.gov) }\end{array}$ \\
\hline Emetine & IkBa phosphorylation inhibitor & $\begin{array}{l}\text { Canonical NF-KB } \\
\text { pathway }\end{array}$ & $\begin{array}{l}\text { Tested in vitro and in vivo in diffuse large B cell } \\
\text { lymphoma cells; induced cell death and demonstrated } \\
\text { significant inhibition of tumor growth [62] }\end{array}$ \\
\hline Lestaurtinib & IkBa phosphorylation inhibitor & $\begin{array}{l}\text { Canonical NF-KB } \\
\text { pathway }\end{array}$ & $\begin{array}{l}\text { Showed biological and clinical activity in phase } 1 / 2 \text { trial } \\
\text { for patients with relapsed or refractory acute myeloid } \\
\text { leukemia [63] }\end{array}$ \\
\hline Mesalamine & Blocks p65-dependent transactivation & $\begin{array}{l}\text { Canonical NF-KB } \\
\text { pathway }\end{array}$ & $\begin{array}{l}\text { Not tested in } M C L \text { cells; first line agent for treating } \\
\text { ulcerative colitis; maintains remission in mild to } \\
\text { moderate UC [64] }\end{array}$ \\
\hline Fenofibrate & $\begin{array}{l}\text { Inhibits the TNF- } \mathrm{a} / \mathrm{NF}-\mathrm{KB} \text { axis to induce apoptosis; } \\
\text { modulates the expression of anti-apoptotic genes } \\
\text { associated with MCL; decreases DNA binding of } \\
\text { NF- } K B\end{array}$ & $\begin{array}{l}\text { Canonical NF-kB } \\
\text { pathway, cross-talk } \\
\text { with TNF signaling }\end{array}$ & $\begin{array}{l}\text { Tested in vitro-decreases growth of Mino, SP53, } \\
\text { and Jeko-1 cell lines; induces apoptosis in MCL cell } \\
\text { lines Mino and Jeko-1 in vitro; decreases cyclin D1 } \\
\text { expression in Mino and SP53 [65] }\end{array}$ \\
\hline
\end{tabular}




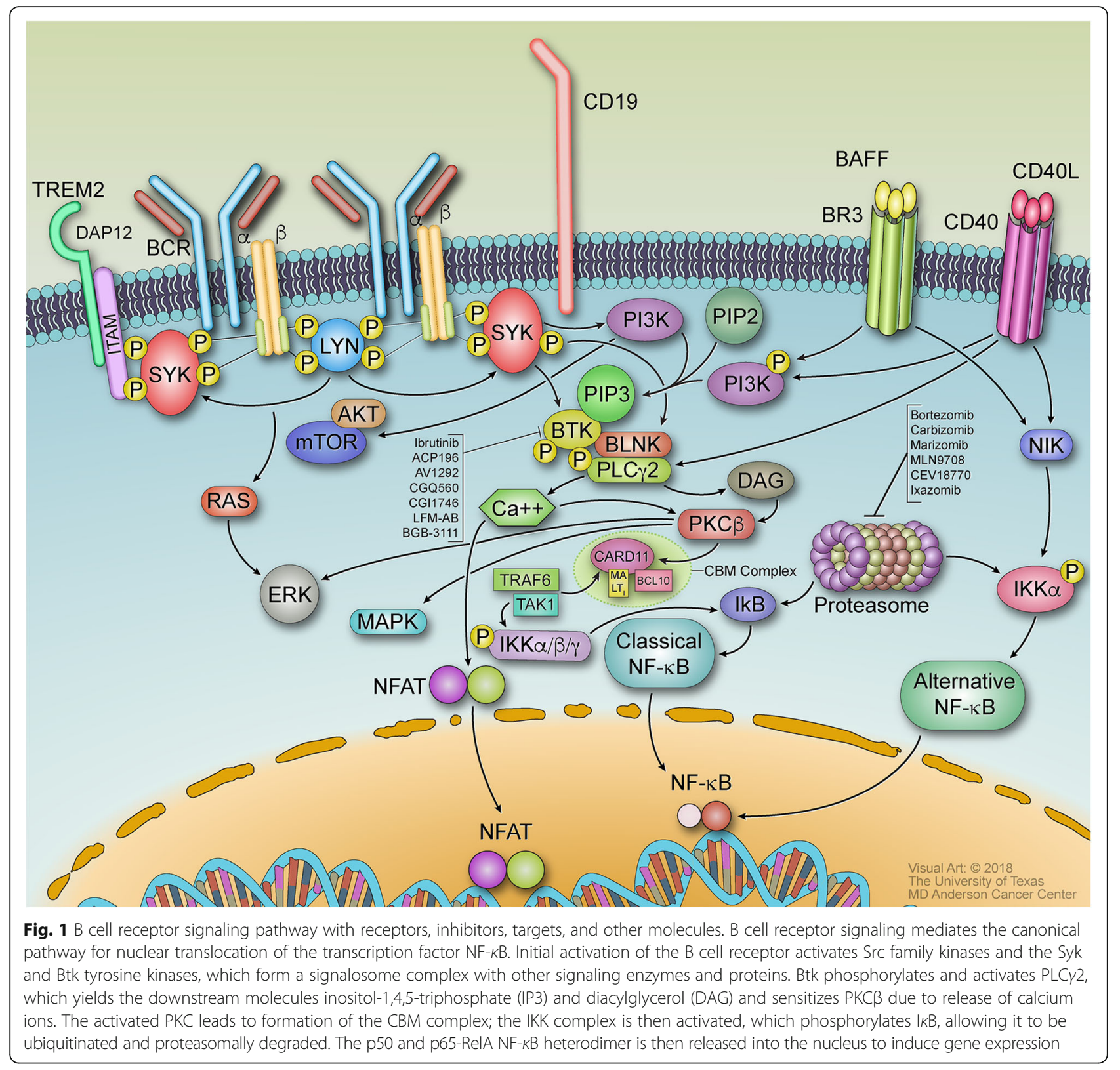

key role of NF- $\mathrm{kB}$ activity in the proliferation of various subtypes of lymphoma cells.

BTK is a major player in initiating the canonical pathway involving BCR signaling. Inhibition of BTK can cause apoptosis in lymphoma cells, which makes BTK a critical therapeutic target [13]. Ibrutinib (PCI-32765) and acalabrutinib, a second-generation BTK inhibitor, effectively block downstream signaling, subsequently inhibiting $\mathrm{B}$ cell activation (Table 1) [14-16]. In ABC-DLBCL and Waldenström macroglobulinemia, ibrutinib is highly effective due to the activation of BTK via mutations in CD79B or the myeloid differentiation primary response gene 88 (MyD88), but in mantle cell lymphoma, these mutations are rare [17-19].
To identify what confers ibrutinib sensitivity in mantle cell lymphoma with respect to NF- $\kappa \mathrm{B}$ signaling, Saba et al. [17] analyzed the gene expression profiles of 55 tumor samples from 43 previously untreated patients with MCL that were about to undergo therapy. MCL cells of the lymph node demonstrated activation of canonical NF- $\kappa \mathrm{B}$ signaling and BCR signaling [17]. Gene expression differed between MCL cells in peripheral blood and lymph nodes because of activation of signaling pathways in the lymph nodes [17]. The ability of tumor cells to proliferate corresponded with the degree of BCR activation.

Saba et al. found that the canonical NF- $\mathrm{kB}$ signature with 18 genes dependent on IKK $\beta$ activation was on average 
2.1-fold more highly expressed in lymph node biopsies than in purified MCL cells $(p<.0001)$ [17]. One set of tumors demonstrated dependence on the lymph node environment for BCR and NF- $\mathrm{KB}$ activation, whereas another set indicated that $\mathrm{BCR}$ and NF- $\mathrm{KB}$ genes were not as independent on the lymph node microenvironment [17]. NF- $\kappa \mathrm{B}-\mathrm{indu}-$ cing kinase (NIK) signature genes, as markers of the non-canonical NF- $\mathrm{kB}$ pathway, were less expressed than the canonical NF- $\mathrm{kB}$ signature genes [17]. In MCL cells from the lymph nodes, SYK and p65 were highly phosphorylated, reflecting BCR-dependent activation of the canonical NF-кB pathway [17]. When ibrutinib was administered to inhibit BTK, ibrutinib reduced phosphorylation of p65 and killed 35 to $50 \%$ of the tumor cells within $48 \mathrm{~h}$ of administration [17]. BCR signaling is activated in the lymph node microenvironment in vivo and appears to promote tumor proliferation and survival, making the canonical pathway a viable target.

TLR signaling Toll-like receptor (TLR) signaling is of particular relevance in mantle cell lymphoma, as TLRs are important proteins involved in the innate immune system. Specifically, increased TLR4 expression in MCL cells can contribute to tumor progression [20]. TLRs recognize pathogen-associated microbial patterns (PAMPs) and danger-associated molecular patterns (DAMPs) to help cells recognize foreign invaders and trigger inflammatory responses. TLR4 activation in patients with recurrent bacterial infections promotes tumor growth and shields MCL cells from surveillance by the immune system [20]. Toll-like receptor signaling is twofold: one pathway involving TLR4 depends on MyD88, mediating early $\mathrm{NF}-\kappa \mathrm{B}$ activation, and the other pathway depends on TIR-domain-containing adapter-inducing interferon- $\beta$ (TRIF), mediating late activation of NF- $\kappa$ B.

Both TLR pathways begin with lipopolysaccharide (LPS) binding to LPS-binding protein and forming a complex that binds CD14 to the cell membrane. LPS is then transferred to MD-2 and TLR-4 [21]. TLR-4 subsequently activates the MyD88-dependent pathway with Mal/TIRAP and the TRIF-dependent pathway with TRAM. Unlike IL-1R signaling, MyD88 interacts with Mal for recruitment to the receptor complex [22]; complexes I, II, and III otherwise form in the same manner as that for IL-1R signaling. MyD88 additionally recruits TNF receptor-associated factor 6 (TRAF6) and members of the interleukin-1 receptor-associated kinase (IRAK) family, i.e., IRAK-1, which interact with BCL10 in complex I. BCL10 then binds to Pellino2 and MALT1 (in complexes II and III, respectively), facilitating the activation of TRAF6 [23]. TRAF6, along with Ubc13 and Uev1A, which are ubiquitin-conjugating proteins, activates the TAK1 complex [24]. The TAK1 complex can then activate IKK, triggering the usual cascade of events in the canonical pathway. Targeting TLR-mediated NF- $\kappa$ B signaling may increase the susceptibility of MCL cells to immune surveillance and subsequently minimize tumor progression.

Stimulation of TLR4 signaling via LPS has been found by Wang et al. to increase proliferation of the following MCL cell lines: SP53, Jeko-1, Mino, and Granta-519 [20]. MCL cells expressed many different TLRs, of which TLR4 was one of the most highly expressed [20]. LPS-induced TLR4 signaling also increased NF- $\kappa$ B phosphorylation and activated expression of important cytokines, including interleukin-1 and the vascular endothelial growth factor (VEGF) in MCL cell lines and primary patient cells with TLR4 and MyD88 expression [20]. LPS-mediated TLR4 signaling in MCL cells also facilitated immune evasion by inhibiting $\mathrm{T}$ cell proliferation. Cells without TLR4 had a much weaker ability to inhibit $\mathrm{T}$ cell proliferation, confirming the key pro-tumor role of TLR4 in MCL cell survival [20].

TLR1/2 and TLR5 have also been found to be expressed in MCL cell lines and primary MCL cells [25]. The activation of TLR2 and TLR5 further activates Akt and MAPK signaling, leading to overexpression of cyclin D1 and D3 and increased proliferation of MCL cells. TLR1/2 and TLR5 activation also affects the canonical NF- $\kappa$ B pathway and enhances the survival and migration of MCL cells [25]. Primary MCL cells have also shown an intermediate response to stimulation with $\mathrm{CpG}$ oligodeoxynucleotides, which are detected by TLR9 [26]. TLR9 upregulates the expression of CD20 upon binding with the CpG motif and interacts with BTK to induce B cell proliferation [26, 27].

TLR signaling interplays with BCR signaling mechanisms, affecting the overall survival of MCL patients. Akhter et al. used the NanoString nCounter technology to digitally quantify BCR and TLR signaling molecules in a cohort of 81 MCL patients [27]. This cohort was split into two subsets: those with high BCR activation and those with low BCR activation ( $>1.5$-fold change in expression, $p<0.05$ ) [27]. There was a significant difference in expression of TLR6, TLR7, and TLR9 between the subsets of patients, with fold changes of 2.2, 1.9, and 2.4 , respectively ( $p<0.05$ for all) [27]. Overexpression of TLR6 and TLR9 was associated with a poor clinical outcome and worse overall survival in patients with hyperreactive BCR signaling [27]. TLR4 expression was not significantly different between the two subsets of patients, which failed to validate the findings of Wang et al. [20] that MCL cells have high expression of TLR4 [27]. TLR9, on the other hand, was overexpressed in the subset with high BCR activation, in sync with the overexpression of key mediators in the BCR signaling pathway, including BTK, BLNK, and SYK, suggesting that BCR may be activated in a tonic, antigen-independent, or restricted antigen manner [27]. Targeting MCL 
through TLR inhibitors in combination with other agents targeting NF- $\kappa \mathrm{B}$ pathways may be a promising therapeutic choice.

TNF-R signaling NF- $\kappa$ B activation can lead to apoptosis or survival, depending on the apoptotic stimulus. Interestingly, TNF- $\alpha$ signaling causes NF- $\kappa$ B to have anti-apoptotic effects, protecting the proliferating tumor cells; inhibition of NF- $\kappa$ B sensitizes tumor cells to TNF- $\alpha$-induced apoptosis [28].

Upon activation, a TNF receptor uses its death domain, tumor necrosis factor receptor type 1-associated death domain (TRADD), to bind to RIP1 and TRAF2 [29]. Once the TNF receptor is endocytosed, TRADD detaches from the receptor and associates with another protein: Fas-associated protein with death domain (FADD). The interaction of FADD with caspase-8 activates a caspase cascade, which leads to apoptosis [30]. Meanwhile, TRAF2 ubiquitinates itself and RIP1, bound to TAB2 and NEMO/ IKK $\gamma$, prompting recruitment of TAK1 (which regulates MAP3K3 activity) and IKK $\beta$. TNF stimulation causes RIP1 to recruit MEKK3/MAP3K3, which phosphorylates IKK $\beta$ [31]. The IKK complex is then activated, leading to the poly-ubiquitination and proteasomal degradation of $\mathrm{I} \kappa \mathrm{B}$, allowing the $\mathrm{p} 50-\mathrm{p} 65$ heterodimer to enter the nucleus. RIP1 can also act independently of TAK1 by interacting with $\mathrm{p} 62$, which leads to activation of atypical protein kinase $\mathrm{C}(\mathrm{aPKC})$ and subsequent activation of the IKK complex [32].

$2^{\prime}$-Deoxy-2'- $\beta$-fluoro-4' -azidocytidine (FNC) is a cytidine analogue that inhibits proliferation of mantle cell lymphoma cells in vitro and in vivo by inducing apoptosis. Zhang et al. found that administration of FNC to Jeko-1 cells induces apoptosis through the signaling of death receptors, which are members of the TNF superfamily [33]. FNC treatment increased expression of TNF- $\alpha$, Fas, and the Fas ligand [33]. Upregulation of TNF- $\alpha$ in combination with inhibition of NF- $\kappa \mathrm{B}$ activation can increase apoptosis in mantle cell lymphoma cells, presenting a route by which MCL tumors can be targeted.

\section{The non-canonical pathway}

The non-canonical pathway is activated by initiation of $B$ cell activation factor (BAFFR), CD40, lymphotoxin $\beta$-receptor (LT $\beta R$ ), or receptor activator for nuclear factor kappa B (RANK) signaling. The non-canonical NF- $k$ B pathway involves the processing of p100, where p100 is phosphorylated by IKK $\alpha$ on the serine residues S866 and S870 and then poly-ubiquitinated (Fig. 2) [34]. This leads to the activation of RelB-p52 complexes, which are heterodimeric subunits of NF- $\kappa$ B. IKK $\alpha$ is activated by the upstream kinase NF- $k$ B-inducing kinase (NIK), which promotes the processing of p100 into the active p52 isoform. NIK is downregulated by the expression of
TRAF2 and TRAF3, which are negative regulators of non-canonical NF- $\kappa$ B signaling that interact with BIRC2 and BIRC3 [1]. Unlike the canonical pathway, the non-canonical pathway does not rely on IKK $\beta$ or IKK $\gamma$ (NEMO); it only needs IKK $\alpha$ to phosphorylate the p52 precursor, p100. Targeting non-canonical signaling mechanisms can overcome resistance to therapies that only target canonical NF- $\kappa$ B signaling.

\section{Interactions with signaling pathways that coordinate with the NF-KB non-canonical pathway}

CD40 signaling When a CD40 ligand binds to the CD40 receptor on the cell membrane, TRAF proteins are recruited to and directly bind to the CD40 receptor. TRAF proteins negatively regulate NIK. When the NF- $\kappa$ B pathway is inactive, NIK is constantly degraded via ubiquitination by TRAF3. NIK activity is also suppressed by expression of cellular inhibitor of apoptosis 1 (cIAP1) and cellular inhibitor of apoptosis 2 (cIAP2) [35]. However, when the pathway is activated via CD40 ligation, TRAF2 and cIAP $1 / 2$ cause TRAF3 to be proteasomally degraded [36]. NIK can then accumulate with increased stability and phosphorylate IKK $\alpha$, which is required for the phosphorylation and processing of p100 to form $\mathrm{p} 52$.

CD40 is expressed in mature B cells, including mantle cell lymphoma cells. While some MCL cells are sensitive to BCR signaling inhibition by ibrutinib, many patients still demonstrate resistance to inhibition of the canonical NF- $\kappa$ B pathway [37]. Culturing the MCL Rec- 1 cell line with the CD40 ligand weakened the ability of ibrutinib to inhibit proliferation of Rec-1 cells. The effectiveness of ibrutinib, a BTK inhibitor, was undermined due to how CD40 signaling activates the NF- $\kappa$ B p52 isoform via the non-canonical pathway, which promotes cell survival in opposition to ibrutinib's inhibitory effects on the canonical pathway [38]. Targeting CD40-mediated NF- $\kappa \mathrm{B}$ signaling, in addition to targeting canonical BCR signaling, may help overcome ibrutinib resistance in patient populations with activated CD40-CD40L pathways [38].

BAFFR signaling B cell-activating factor receptor (BAFFR) signaling mechanisms are similar to those of CD40 signaling. BAFFR is a member of the TNFR family, and it predominantly activates the non-canonical NF- $\kappa \mathrm{B}$ pathway [39]. BAFFR can interact with TRAF3 but not TRAF2, which is why BAFFR cannot trigger the canonical pathway. Degradation of TRAF3 triggers non-canonical NF- $\kappa B$ signaling [40]. This leads to 100 processing via NIK activation and the same downstream molecular interactions as with CD40 signaling. BAFFR may be a key biomarker of both normal and abnormal B cells, especially due to its role in activating the non-canonical NF- $\kappa \mathrm{B}$ 


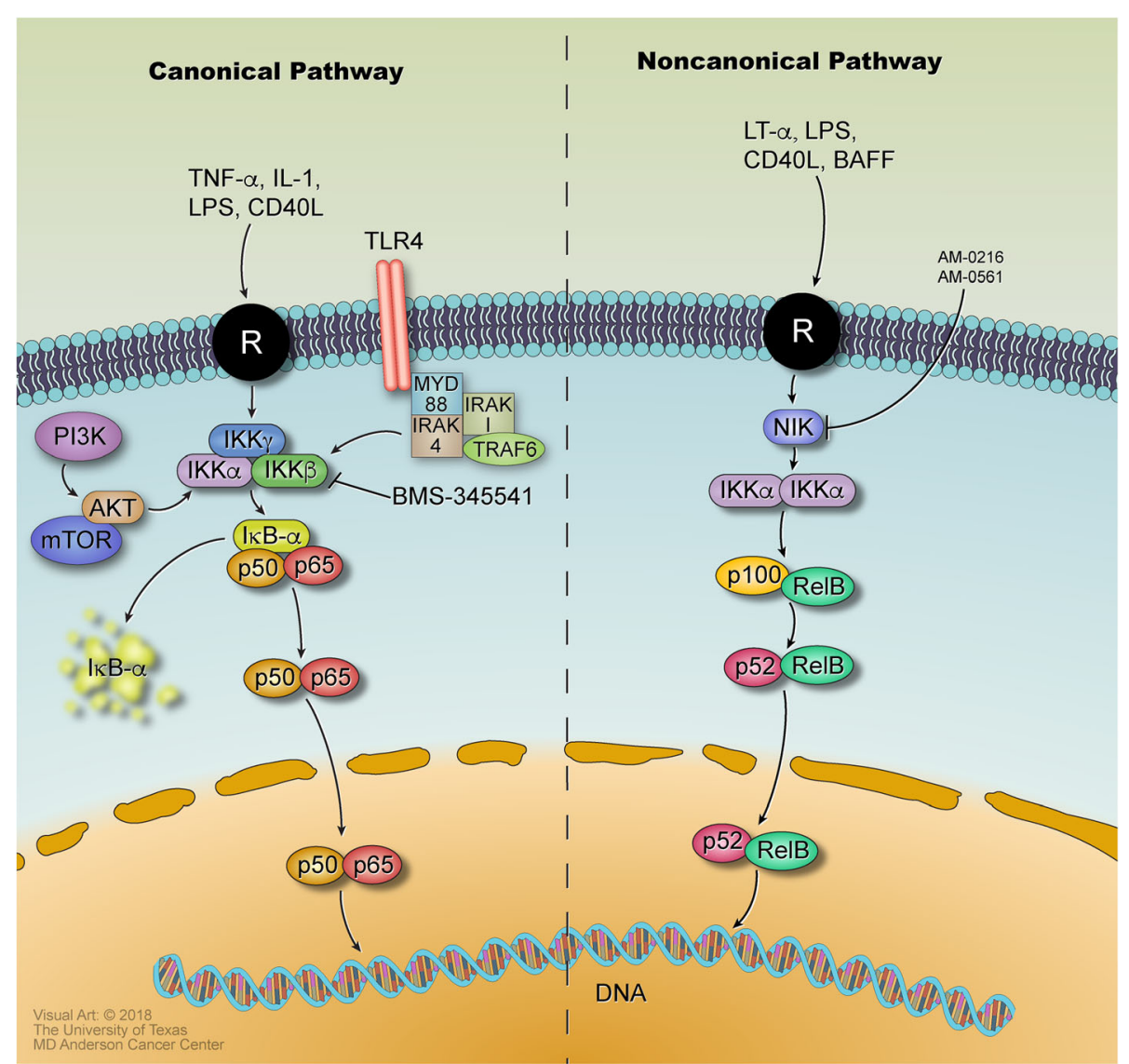

Fig. 2 NF-KB signaling pathways with receptors, inhibitors, targets, and other molecules The canonical and non-canonical pathways for NF- $k B$ signaling are mediated by various receptors and signaling molecules, including toll-like receptors (TLR), tumor necrosis factor receptors (TNFR), interleukin-1 receptor (IL-1R), CD40, initiation of B cell activation factor (BAFFR), lymphotoxin $\beta$ - receptor (LTßR), and receptor activator for nuclear factor kappa B (RANK). The canonical NF-kB pathway involves the inhibition of NF-kB by IKB, which binds to the p50-p65 heterodimer in the cytoplasm and prevents it from entering the nucleus. Activation of BCR, TNFR, and IL-1R receptors initiates adapter protein and signaling kinase responses, leading to activation of the IKB kinase (IKK) complex. Kinases in the IKK complex phosphorylate IKB and lead to its poly-ubiquitination and proteasomal degradation. This allows the p50 and p65-RelA heterodimer (a complex from the NF-KB family) to be released into the nucleus to induce gene expression. In the non-canonical pathway, IKKa is activated by the upstream kinase NF-KB-inducing kinase (NIK), which promotes the processing of p100 into the active RelB-p52 isoform of NF-KB. NIK is downregulated by the expression of TRAF2 and TRAF3, which are negative regulators of non-canonical NF-KB signaling that interact with BIRC2 and BIRC3 [1]. Unlike the canonical pathway, the non-canonical pathway does not rely on IKK $\beta$ or IKKY (NEMO); it only needs IKKa to phosphorylate the p52 precursor, p100

pathway. Targeting BAFFR-mediated NF- $\kappa$ B signaling may offer a novel approach in suppressing neoplastic B cell maturation and proliferation.

\section{Interaction with the PI3K/AKT pathway}

$\mathrm{NF}-\kappa \mathrm{B}$ signaling is also mediated through interactions with other pathways, such as the PI3K/Akt pathway. In Burkitt's lymphoma, an aggressive form of non-Hodgkin lymphoma, NF- $\kappa$ B activation and STAT3 activation depend on upstream signaling of phosphatidylinositol 3-kinase (PI3K), which plays a key role in survival signaling [41]. Inhibition of PI3K blocks interleukin-1 signaling (IL-1), preventing eventual translocation of the p65-RelA heterodimer to the nucleus. Lipid products of PI3K activate the serine/threonine kinase Akt/PKB, which mediates cell survival and proliferation [42]. While Akt does not directly phosphorylate NF- $\kappa \mathrm{B}$, it affects the canonical NF- $\kappa \mathrm{B}$ signaling pathway by phosphorylating IKK $\alpha$, which targets the ІкB inhibitor protein and allows $\mathrm{NF}-\kappa \mathrm{B}$ to translocate to the nucleus [42]. Overexpression of IKB conversely interferes with the ability of PI3K and Akt to induce oncogenic transformation, indicating that the PI3K/Akt and NF- $\kappa$ B pathways depend on one another.

Through gene expression profiling, several genes in mantle cell lymphoma cells have been identified that relate to the PI3K/Akt pathway; the following genes were found to be altered or upregulated: PIK3CA, PDK2, PDPK1, AKT1, RPS6KB2, FOXO3A, PPP2R2C, and PDK1 [43]. 
The PI3K/Akt pathway may confer resistance to apoptosis in MCL cells. PI3K inhibitors such as duvelisib and idelalisib have been found to have anti-tumor activity in relapsed MCL [44, 45]. PI3K/Akt survival signaling is supplemented by the survival signaling of NF- $\kappa \mathrm{B}$, suggesting that targeting both pathways in a joint manner may be highly effective in limiting MCL cell proliferation and preventing tumor growth in patients.

\section{Relevance of NF- $\kappa B$ pathways for the treatment of MCL}

Mantle cell lymphoma does not have any single clear oncogenic driver and is heterogeneous, characterized by mutations in genes including ATM, CCND1, UBR5, TP53, BIRC3, NOTCH1/2, and TRAF2 [46]. Mutations in elements of the canonical NF- $\kappa$ B pathway, such as the CBM complex or IKK-beta, cause activation of the canonical pathway. This allows drugs such as ibrutinib and acalabrutinib, BTK inhibitors, to effectively inhibit BCR signaling and suppress growth in cells sensitive to BCR signaling inhibition [47]. MCL cells that are resistant to $\mathrm{BCR}$ signaling inhibition tend to have somatic mutations in inhibitors of the non-canonical NF- $\kappa$ B pathway, such as cIAP1, cIAP2, and TRAF2/3; these mutations cause resistant cell lines (Z-138, Maver-1) to depend on the deregulated non-canonical NF- $\kappa \mathrm{B}$ pathway for survival and proliferation (Fig. 2).

When PKC-B, an important kinase upstream of the CBM complex in BCR signaling, was depleted via sh-RNA, proliferation of the ibrutinib-sensitive MCL cell line Jeko-1 was suppressed, while the insensitive cell line Granta-519 was left unaffected. This indicates that a subset of cell lines strongly depends on canonical NF- $\kappa \mathrm{B}$ signaling. Treatment with sotrastaurin (STN) was also found to selectively modulate $\mathrm{I} \kappa \mathrm{B} \alpha$ phosphorylation and reduce RelB cleavage, which is a marker of CBM complex activity, in STN-sensitive MCL cell lines [48]. In addition, the CBM complex component CARD11 appeared to be highly expressed in sensitive MCL lines, suggesting that BCR pathway components can be deregulated to treat cells that are sensitive to inhibition of the canonical NF- $\kappa$ B pathway [49].

MCL tumors can also be targeted via other pathways that interact with NF- $\kappa \mathrm{B}$ signaling, for instance, through the PI3K /Akt pathway, CD40 signaling, BAFFR signaling, or transglutaminase (TG2) signaling. The expression of transglutaminase (TG2), a calcium-dependent protein encoded by the TGM2 gene associated with tumor cell proliferation, metastasis, and drug resistance, is closely linked with constitutive activation of NF- $\kappa \mathrm{B}$ [50]. Upregulation of TG2 expression increased IL6 expression 1.8- to 2.9-fold and stimulated autophagy formation, a protective mechanism for tumor cells [50]. In comparison with normal B cells, patients with a blastoid type of MCL, an aggressive variant with a worse overall survival, displayed elevated TGM2 levels with up to 150-fold increases; these blastoid MCL subtypes also had higher TGM2 levels than classical MCL [50]. By silencing TG2 via CRISPR/Cas9, Zhang et al. observed that p53, p21, and p27 levels increased and cyclin gene levels decreased, indicating cell cycle arrest, levels of anti-apoptotic genes including BCL-XL and BCL-2 decreased, and levels of pro-apoptopic genes including BAX, BAK, and NOXA increased [50]. NF- $\kappa$ B p50 and p65 DNA-binding activity, downstream activation of IL8, p-STAT3 expression, and IL6 levels were significantly decreased in TG2 knockout MCL cells whereas signaling activity increased in TG2 overexpression cells [50]. TG2 silencing also conferred sensitivity to chemotherapeutic drugs whereas cells overexpressing TG2 exhibited drug resistance with higher IC50 values [50]. In patients with bortezomib resistance, TG2 signaling can be inhibited by a calcium blocker such as perillyl alcohol and administered in combination with bortezomib to suppress NF- $\kappa$ B expression and improve MCL cell sensitivity to bortezomib [51]. Inhibiting autophagy in MCL cells via TG2 silencing may thus be a promising therapeutic choice to overcome chemotherapy resistance.

Many targeted therapies have focused on targeting B cell receptor signaling in MCL cells, which indirectly reduces canonical NF- $\kappa$ B signaling. Direct inhibitors of NF- $\kappa$ B are scarce, but more targeted therapies are focusing on inhibition of non-canonical signaling and cross-talk with other pathways, such as the PI3K/Akt pathway to overcome resistance to inhibitors of the canonical pathway. For instance, the combination of TGR-1202, a PI3K delta inhibitor, with ibrutinib had an overall response rate of $67 \%$ with six out of nine patients achieving a partial response in a phase I/Ib multicenter trial for patients with relapsed/refractory MCL [52]. Other combination therapies that target both canonical and non-canonical pathways have also been effective in inhibiting MCL cell growth and proliferation (Table 2). For instance, the combination of CC-292 with NIK inhibitors, AM-0216 and AM-0561, in Z138 and MAVER-1, cell lines resistant to CC-292 and ibrutinib, resulted in a significant decrease in p52 levels, via inhibition of the non-canonical pathway, and a complete lack of ІкB phosphorylation, indicating total inhibition of the NF- $\kappa \mathrm{B}$ pathway [53]. This combination was also effective in primary MCL cells with BIRC3 inactivation and is a promising therapeutic choice for further investigation in vivo and in the clinical setting [53].

\section{Conclusions}

Overall, the NF- $\kappa \mathrm{B}$ pathways have numerous molecular mechanisms that lead to the eventual expression of NF- $\kappa \mathrm{B}$ target genes. These genes prompt inflammatory responses, immune regulation, and cell proliferation via the canonical pathway and $B$ cell maturation and lymphoid organogenesis via the non-canonical pathway. The multifaceted NF- $\kappa$ B pathways play a crucial role in the growth and proliferation 
Table 2 Combination therapies targeting the NF-kB pathway

\begin{tabular}{|c|c|c|}
\hline Combination therapy & Target pathway and mechanism & Tested in MCL cells/patients? \\
\hline Ibrutinib with rituximab & $\begin{array}{l}\text { Canonical and non-canonical NF-kB pathways; } \\
\text { inhibits BTK; rituximab decreases phosphorylation } \\
\text { of NIK, IKB kinase, and IKBa; diminishes IKK kinase } \\
\text { activity; and decreases NF-KB DNA-binding activity }\end{array}$ & $\begin{array}{l}\text { Yes; ongoing phase II trial at the MD Anderson Cancer } \\
\text { Center of rituximab in combination with ibrutinib in } \\
\text { relapsed/refractory MCL (clinicaltrials.gov) }\end{array}$ \\
\hline $\begin{array}{l}\text { Thalidomide with } \\
\text { rituximab }\end{array}$ & $\begin{array}{l}\text { Canonical and non-canonical NF-KB pathway; } \\
\text { thalidomide inhibits IKK and reduces TNF-a } \\
\text { production, along with effects of rituximab }\end{array}$ & $\begin{array}{l}\text { Yes-thalidomide combined with rituximab has antitumor } \\
\text { activity in relapsed/refractory } M C L ; 81 \% \text { overall response } \\
\text { rate to rituximab plus thalidomide [66] }\end{array}$ \\
\hline $\begin{array}{l}\text { Lenalidomide with } \\
\text { rituximab }\end{array}$ & $\begin{array}{l}\text { Canonical and non-canonical NF-KB pathway; } \\
\text { downregulates pro-inflammatory cytokines, } \\
\text { such as TNF-a, IL-1, and IL-6, along with effects } \\
\text { of rituximab }\end{array}$ & $\begin{array}{l}\text { Yes-overall response rate of } 87 \% \text { when combined with } \\
\text { rituximab in MCL patients [67] }\end{array}$ \\
\hline TGR-1202 with ibrutinib & $\begin{array}{l}\text { Cross-talk between NF-KB and PI3K/Akt pathways; } \\
\text { TGR-1202 inhibits PI3K Delta }\end{array}$ & $\begin{array}{l}\text { Yes-tested in relapsed or refractory } M C L \text { and } C L L \text { patients } \\
\text { in combination with ibrutinib in a phase } 1 / 1 \mathrm{~b} \text { study; overall } \\
\text { response rate of } 85 \% \text { in combination with ibrutinib }(11 / 13) \text { [52] }\end{array}$ \\
\hline $\begin{array}{l}\text { Perillyl alcohol (calcium } \\
\text { blocker) with } \\
\text { bortezomib }\end{array}$ & $\begin{array}{l}\text { Cross-talk between NF-KB and TG2 signaling; } \\
\text { inhibition of autophagy to improve sensitivity } \\
\text { to bortezomib }\end{array}$ & $\begin{array}{l}\text { Not tested in patients but tested in MCL cells; was found to } \\
\text { suppress NF-KB signaling and improve cytotoxicity of } \\
\text { bortezomib [51] }\end{array}$ \\
\hline $\begin{array}{l}\text { CC-292 with } \\
\text { lenalidomide and NIK } \\
\text { inhibitors, AM-0216 } \\
\text { and AM-0561 }\end{array}$ & $\begin{array}{l}\text { Canonical and non-canonical NF-KB pathway; } \\
\text { CC-292 inhibits BTK in a highly selective manner; } \\
\text { lenalidomide downregulates pro-inflammatory } \\
\text { cytokines, such as TNF-a, IL-1, and IL-6; NIK } \\
\text { inhibitors inhibit alternative NF-KB signaling }\end{array}$ & $\begin{array}{l}\text { Not tested in patients, but tested in MCL cell lines and primary } \\
\text { cells; CC-292 significantly reduced BTK phosphorylation and } \\
\text { its activity was enhanced by lenalidomide co-treatment; } \\
\text { combination of CC- } 292 \text { with NIK inhibitors had a significant } \\
\text { cooperative effect that inhibited cell growth and induced } \\
\text { apoptosis in Z138 and MAVER-1 [53] }\end{array}$ \\
\hline
\end{tabular}

of mantle cell lymphoma cells. Drugs that target various components of the NF- $\kappa \mathrm{B}$ pathway have the potential to treat MCL, depending on the pathway to which the cells are sensitive. Targeting NF- $\kappa \mathrm{B}$ mechanisms may prove to be a valuable tool in the development of targeted agents to overcome drug resistance and can lead to effective therapies for mantle cell lymphoma.

\footnotetext{
Abbreviations

ABC-DLBCL: Activated B cell-like diffuse large B cell lymphoma; BAFF/ TNFSF13B: B cell-activating factor; BAFFR: B cell-activating factor receptor; BCAP: B cell adaptor for phosphoinositide 3-kinase; BCL10: B cell lymphoma/ leukemia 10 protein; BCR: B cell receptor; BLK: B lymphocyte tyrosine kinase; BLNK: B cell linker protein; BTK: Bruton's tyrosine kinase; C40L/TNFS5: CD40 ligand; CBM: CARD11-BCL10-MALT1 signalosome complex; CIAP1: Cellular inhibitor of apoptosis 1; CIAP2: Cellular inhibitor of apoptosis 2; CLL: Chronic lymphocytic leukemia; DAG: Diacylglycerol; DAMP: Danger-associated molecular patterns; DLBCL: Diffuse large B cell lymphoma; ER: Endoplasmic reticulum; FADD: Fas-associated protein with death domain; FNC: 2'-Deoxy2'-ß-fluoro-4'-azidocytidine; GCB-DLBCL: Germinal center B cell-like diffuse large B cell lymphoma; HDAC: Histone deacetylase; IKK: IKB kinase; IKKa: IKB kinase; IKKR: IKB kinase; IKKY: IKB kinase; IL-1: Interleukin-1; IL-1R: Interleukin-1 receptor; IP3: Inositol-1,4,5-triphosphate; IRAK: Interleukin-1 receptorassociated kinase; ITAM: Immunoreceptor tyrosine-based activation motifs; LPS: Lipopolysaccharide; LTßR: Lymphotoxin $\beta$-receptor; MALT1: Mucosaassociated lymphoid tissue lymphoma translocation protein 1; MCL: Mantle cell lymphoma; MyD88: Myeloid differentiation primary response gene 88; NF-KB: Nuclear factor kappa-light-chain enhancer of activated B cells; NIK: NFKB-inducing kinase; PAMP: Pathogen-associated microbial patterns; PCl32765: Ibrutinib, an inhibitor of Bruton's tyrosine kinase; PI3K: Phosphatidylinositol 3-kinase; PKC 3 : Protein kinase C beta; PLCY2: 1 Phosphatidylinositol-4,5-bisphosphate phosphodiesterase gamma-2; RANK: Receptor activator for nuclear factor kappa B; STN: Sotrastaurin; SYK: Spleen tyrosine kinase; TG2: Transglutaminase; TLR: Toll-like microbial pattern recognition receptors; TLR1: Toll-like receptor 1; TLR2: Toll-like receptor 2; TLR4: Toll-like receptor 4; TLR5: Toll-like receptor 5; TLR9: Toll-like receptor 9; TNFR: Tumor necrosis factor receptor; TNFSF3: Lymphotoxin $\beta$; TNFa: Tumor necrosis factor alpha; TRADD: Tumor necrosis factor receptor type 1-associated death domain protein; TRAF: TNF receptor-associated
}

factor; TRIF: TIR-domain-containing adapter-inducing interferon- $\beta$; VEGF: Vascular endothelial growth factor

\section{Funding}

This work was supported by the generous contributions made to the B-cell Lymphoma Moon Shot Program at MD Anderson Cancer Center.

\section{Authors' contributions}

SB was the major contributor in compiling research for and writing the manuscript. MA and EL made equal contributions in revising the manuscript. FY helped prepare the figures and revise the manuscript. KN and MW made final revisions to the manuscript and oversaw its completion. All authors have read and approved this manuscript.

Ethics approval and consent to participate

Not applicable

\section{Competing interests}

The authors declare that they have no competing interests.

\section{Publisher's Note}

Springer Nature remains neutral with regard to jurisdictional claims in published maps and institutional affiliations.

Received: 29 January 2018 Accepted: 28 May 2018 Published online: 15 June 2018

\section{References}

1. Rahal R, Frick M, Romero R, Korn JM, Kridel R, Chan FC, Meissner B, Bhang $H E$, Ruddy D, Kauffmann A, et al. Pharmacological and genomic profiling identifies NF-kappaB-targeted treatment strategies for mantle cell lymphoma. Nat Med. 2014;20:87-92.

2. Broide DH, Lawrence T, Doherty T, Cho JY, Miller M, McElwain K, McElwain $\mathrm{S}$, Karin M. Allergen-induced peribronchial fibrosis and mucus production mediated by IkappaB kinase beta-dependent genes in airway epithelium. Proc Natl Acad Sci U S A. 2005;102:17723-8.

3. Lawrence T, Gilroy DW, Colville-Nash PR, Willoughby DA. Possible new role for NF-kappaB in the resolution of inflammation. Nat Med. 2001;7:1291-7. 
4. Taylor JA, Bren GD, Pennington KN, Trushin SA, Asin S, Paya CV. Serine 32 and serine 36 of IkappaBalpha are directly phosphorylated by protein kinase CKII in vitro. J Mol Biol. 1999;290:839-50.

5. Gauld SB, Cambier JC. Src-family kinases in B-cell development and signaling. Oncogene. 2004;23:8001-6.

6. Fu C, Turck CW, Kurosaki T, Chan AC. BLNK: a central linker protein in B cell activation. Immunity. 1998;9:93-103.

7. Marcotte DJ, Liu YT, Arduini RM, Hession CA, Miatkowski K, Wildes CP, Cullen PF, Hong V, Hopkins BT, Mertsching E, et al. Structures of human Bruton's tyrosine kinase in active and inactive conformations suggest a mechanism of activation for TEC family kinases. Protein Sci. 2010;19:429-39.

8. Rohacs T. Regulation of transient receptor potential channels by the phospholipase C pathway. Adv Biol Regul. 2013;53:341-55.

9. Blonska M, Lin X. NF-kappaB signaling pathways regulated by CARMA family of scaffold proteins. Cell Res. 2011;21:55-70.

10. Hewamana S, Alghazal S, Lin TT, Clement M, Jenkins C, Guzman ML, Jordan CT, Neelakantan S, Crooks PA, Burnett AK, et al. The NF-kappaB subunit Rel $A$ is associated with in vitro survival and clinical disease progression in chronic lymphocytic leukemia and represents a promising therapeutic target. Blood. 2008;111:4681-9.

11. Davis RE, Brown KD, Siebenlist U, Staudt LM. Constitutive nuclear factor kappaB activity is required for survival of activated B cell-like diffuse large B cell lymphoma cells. J Exp Med. 2001;194:1861-74.

12. Bognar MK, Vincendeau M, Erdmann T, Seeholzer T, Grau M, Linnemann JR, Ruland J, Scheel CH, Lenz P, Ott G, et al. Oncogenic CARMA1 couples NFkappaB and beta-catenin signaling in diffuse large B-cell lymphomas. Oncogene. 2016;35:4269-81.

13. Seda V, Mraz M. B-cell receptor signalling and its crosstalk with other pathways in normal and malignant cells. Eur J Haematol. 2015;94:193-205.

14. Honigberg LA, Smith AM, Sirisawad M, Verner E, Loury D, Chang B, Li S, Pan Z, Thamm DH, Miller RA, Buggy JJ. The Bruton tyrosine kinase inhibitor PCl32765 blocks B-cell activation and is efficacious in models of autoimmune disease and B-cell malignancy. Proc Natl Acad Sci U S A. 2010;107:13075-80.

15. Wu J, Zhang M, Liu D. Acalabrutinib (ACP-196): a selective secondgeneration BTK inhibitor. J Hematol Oncol. 2016;9:21.

16. Wu J, Liu C, Tsui ST, Liu D. Second-generation inhibitors of Bruton tyrosine kinase. J Hematol Oncol. 2016;9:80.

17. Saba NS, Liu D, Herman SE, Underbayev C, Tian X, Behrend D, Weniger MA, Skarzynski M, Gyamfi J, Fontan L, et al. Pathogenic role of B-cell receptor signaling and canonical NF-kappaB activation in mantle cell lymphoma. Blood. 2016;128:82-92

18. Davis RE, Ngo VN, Lenz G, Tolar P, Young RM, Romesser PB, Kohlhammer H, Lamy L, Zhao H, Yang $Y$, et al. Chronic active B-cell-receptor signalling in diffuse large B-cell lymphoma. Nature. 2010;463:88-92.

19. Treon SP, Tripsas CK, Meid K, Warren D, Varma G, Green R, Argyropoulos KV, Yang G, Cao Y, Xu L, et al. Ibrutinib in previously treated Waldenstrom's macroglobulinemia. N Engl J Med. 2015;372:1430-40.

20. Wang L, Zhao Y, Qian J, Sun L, Lu Y, Li H, Li Y, Yang J, Cai Z, Yi Q. Toll-like receptor-4 signaling in mantle cell lymphoma: effects on tumor growth and immune evasion. Cancer. 2013;119:782-91.

21. Nagai $Y$, Akashi S, Nagafuku M, Ogata M, Iwakura Y, Akira S, Kitamura T, Kosugi A, Kimoto M, Miyake K. Essential role of MD-2 in LPS responsiveness and TLR4 distribution. Nat Immunol. 2002;3:667-72.

22. Verstak B, Nagpal K, Bottomley SP, Golenbock DT, Hertzog PJ, Mansell A. MyD88 adapter-like (Mal)/TIRAP interaction with TRAF6 is critical for TLR2and TLR4-mediated NF-kappaB proinflammatory responses. J Biol Chem. 2009;284:24192-203.

23. Liu Y, Dong W, Chen L, Xiang R, Xiao H, De G, Wang Z, Qi Y. BCL10 mediates lipopolysaccharide/toll-like receptor-4 signaling through interaction with Pellino2. J Biol Chem. 2004;279:37436-44.

24. Yamamoto M, Okamoto T, Takeda K, Sato S, Sanjo H, Uematsu S, Saitoh T, Yamamoto N, Sakurai H, Ishii K, et al. Key function for the Ubc13 E2 ubiquitinconjugating enzyme in immune receptor signaling. Nat Immunol. 2006;7:962-70.

25. Mastorci K, Muraro E, Pasini E, Furlan C, Sigalotti L, Cinco M, Dolcetti R, Fratta E. Toll-like receptor $1 / 2$ and 5 ligands enhance the expression of cyclin D1 and D3 and induce proliferation in mantle cell lymphoma. PLoS One. 2016;11:e0153823.

26. Jahrsdorfer B, Muhlenhoff $L$, Blackwell SE, Wagner M, Poeck $H$, Hartmann E, Jox R, Giese T, Emmerich B, Endres S, et al. B-cell lymphomas differ in their responsiveness to $\mathrm{CpG}$ oligodeoxynucleotides. Clin Cancer Res. 2005;11:1490-9.
27. Akhter A, Street L, Ghosh S, Burns BF, Elyamany G, Shabani-Rad MT, Stewart DA, Mansoor A. Concomitant high expression of toll-like receptor (TLR) and B-cell receptor (BCR) signalling molecules has clinical implications in mantle cell lymphoma. Hematol Oncol. 2017;35:79-86.

28. Wang CY, Cusack JC Jr, Liu R, Baldwin AS Jr. Control of inducible chemoresistance: enhanced anti-tumor therapy through increased apoptosis by inhibition of NF-kappaB. Nat Med. 1999;5:412-7.

29. Hsu H, Huang J, Shu HB, Baichwal V, Goeddel DV. TNF-dependent recruitment of the protein kinase RIP to the TNF receptor-1 signaling complex. Immunity. 1996;4:387-96.

30. Hu WH, Johnson H, Shu HB. Activation of NF-kappaB by FADD, Casper, and caspase-8. J Biol Chem. 2000;275:10838-44.

31. Lee TH, Huang Q, Oikemus S, Shank J, Ventura JJ, Cusson N, Vaillancourt RR, Su B, Davis RJ, Kelliher MA. The death domain kinase RIP1 is essential for tumor necrosis factor alpha signaling to p38 mitogen-activated protein kinase. Mol Cell Biol. 2003;23:8377-85

32. Sanz L, Sanchez P, Lallena MJ, Diaz-Meco MT, Moscat J. The interaction of p62 with RIP links the atypical PKCs to NF-kappaB activation. EMBO J. 1999;18:3044-53.

33. Zhang $Y$, Zhang R, Ding X, Peng B, Wang N, Ma F, Peng Y, Wang Q, Chang J. FNC efficiently inhibits mantle cell lymphoma growth. PLoS One. 2017;12:e0174112.

34. Fong A, Sun SC. Genetic evidence for the essential role of beta-transducin repeat-containing protein in the inducible processing of NF-kappa B2/p100. J Biol Chem. 2002;277:22111-4

35. Demchenko YN, Brents LA, Li Z, Bergsagel LP, McGee LR, Kuehl MW. Novel inhibitors are cytotoxic for myeloma cells with NFkB inducing kinasedependent activation of NFkB. Oncotarget. 2014;5:4554-66.

36. Liao G, Zhang M, Harhaj EW, Sun SC. Regulation of the NF-kappaB-inducing kinase by tumor necrosis factor receptor-associated factor 3-induced degradation. J Biol Chem. 2004;279:26243-50.

37. Martin P, Maddocks KJ, Noto K, Christian B, Furman RR, Andritsos LA, Flynn JM, Jones JA, Ruan J, Chen-Kiang S, et al. Poor overall survival of patients with ibrutinib-resistant mantle cell lymphoma. Blood. 2014;124:3047.

38. Sun Z, Luo L. Abstract 1298: CD40L-CD40 signaling on B-cell lymphoma response to BTK inhibitors. Cancer Res. 2016;76:1298.

39. Claudio E, Brown K, Park S, Wang H, Siebenlist U. BAFF-induced NEMOindependent processing of NF-kappa B2 in maturing B cells. Nat Immunol. 2002;3:958-65.

40. Morrison MD, Reiley W, Zhang M, Sun SC. An atypical tumor necrosis factor (TNF) receptor-associated factor-binding motif of B cell-activating factor belonging to the TNF family (BAFF) receptor mediates induction of the noncanonical NF-kappaB signaling pathway. J Biol Chem. 2005; 280:10018-24.

41. Han SS, Yun H, Son DJ, Tompkins VS, Peng L, Chung ST, Kim JS, Park ES, Janz S: NF-kappaB/STAT3/PI3K signaling crosstalk in iMyc E mu B lymphoma. Mol Cancer 2010, 9:97.

42. Bai $D$, Ueno L, Vogt PK. Akt-mediated regulation of NFkappaB and the essentialness of NFkappaB for the oncogenicity of PI3K and Akt. Int J Cancer. 2009;125:2863-70.

43. Rizzatti EG, Falcao RP, Panepucci RA, Proto-Siqueira R, Anselmo-Lima WT, Okamoto OK, Zago MA. Gene expression profiling of mantle cell lymphoma cells reveals aberrant expression of genes from the PI3K-AKT, WNT and TGFbeta signalling pathways. Br J Haematol. 2005;130:516-26.

44. Flinn IW, Kahl BS, Leonard JP, Furman RR, Brown JR, Byrd JC, WagnerJohnston ND, Coutre SE, Benson DM, Peterman S, et al. Idelalisib, a selective inhibitor of phosphatidylinositol 3-kinase-delta, as therapy for previously treated indolent non-Hodgkin lymphoma. Blood. 2014;123:3406-13.

45. Wang J, Zhang V, Bell T, Liu Y, Guo H, Zhang L. The effects of PI3K- $\delta / Y$ inhibitor, duvelisib, in mantle cell lymphoma in vitro and in patient-derived xenograft studies. Blood. 2016;128:3016.

46. Saba N, Wiestner A. Do mantle cell lymphomas have an 'Achilles heel'? Curr Opin Hematol. 2014;21:350-7.

47. Colomer D, Campo E. Unlocking new therapeutic targets and resistance mechanisms in mantle cell lymphoma. Cancer Cell. 2014;25:7-9.

48. Rauert-Wunderlich H, Rudelius M, Ott G, Rosenwald A. Targeting protein kinase C in mantle cell lymphoma. Br J Haematol. 2016;173:394-403.

49. Knies N, Alankus B, Weilemann A, Tzankov A, Brunner K, Ruff T, Kremer M, Keller UB, Lenz G, Ruland J. Lymphomagenic CARD11/BCL10/MALT1 signaling drives malignant B-cell proliferation via cooperative NF-kappaB and JNK activation. Proc Natl Acad Sci U S A. 2015;112:E7230-8. 
50. Zhang H, Chen Z, Miranda RN, Medeiros LJ, McCarty N. TG2 and NF-kappaB signaling coordinates the survival of mantle cell lymphoma cells via IL6mediated autophagy. Cancer Res. 2016;76:6410-23.

51. Jung HJ, Chen Z, Wang M, Fayad L, Romaquera J, Kwak LW, McCarty N. Calcium blockers decrease the bortezomib resistance in mantle cell lymphoma via manipulation of tissue transglutaminase activities. Blood. 2012;119:2568-78

52. Davids MS, Kim HT, Nicotra A, Savell A, Francoeur K, Hellman JM, Miskin H, Sportelli P, Bashey A, Stampleman L, et al. Updated results of a multicenter phase I/IB study of TGR-1202 in combination with ibrutinib in patients with relapsed or refractory MCL or CLL. Hematol Oncol. 2017;35:54-5.

53. Vidal-Crespo A, Rodriguez V, Matas-Cespedes A, Lee E, Rivas-Delgado A, Giné E, Navarro A, Beà S, Campo E, López-Guillermo A, et al. The Bruton tyrosine kinase inhibitor CC-292 shows activity in mantle cell lymphoma and synergizes with lenalidomide and NIK inhibitors depending on nuclear factor-KB mutational status. Haematologica. 2017;102:e447.

54. Wang ML, Rule S, Martin P, Goy A, Auer R, Kahl BS, Jurczak W, Advani RH, Romaguera JE, Williams ME, et al. Targeting BTK with ibrutinib in relapsed or refractory mantle-cell lymphoma. N Engl J Med. 2013;369:507-16.

55. Wang M, Rule S, Zinzani PL, Goy A, Casasnovas O, Smith SD, Damaj G, Doorduijn J, Lamy T, Morschhauser F, et al. Acalabrutinib in relapsed or refractory mantle cell lymphoma (ACE-LY-004): a single-arm, multicentre, phase 2 trial. Lancet. 2018;391:659-67.

56. Fisher Rl, Bernstein SH, Kahl BS, Djulbegovic B, Robertson MJ, de Vos S, Epner E, Krishnan A, Leonard JP, Lonial S, et al. Multicenter phase II study of bortezomib in patients with relapsed or refractory mantle cell lymphoma. J Clin Oncol. 2006;24:4867-74.

57. Jazirehi AR, Huerta-Yepez S, Cheng G, Bonavida B. Rituximab (chimeric anti-CD20 monoclonal antibody) inhibits the constitutive nuclear factor\{kappa\}B signaling pathway in non-Hodgkin's lymphoma B-cell lines: role in sensitization to chemotherapeutic drug-induced apoptosis. Cancer Res. 2005;65:264-76.

58. Kahl BS, Spurgeon SE, Furman RR, Flinn IW, Coutre SE, Brown JR, Benson DM, Byrd JC, Peterman S, Cho Y, et al. A phase 1 study of the PI3Kdelta inhibitor idelalisib in patients with relapsed/refractory mantle cell lymphoma (MCL). Blood. 2014;123:3398-405.

59. Youn HS, Lee JY, Saitoh SI, Miyake K, Hwang DH. Auranofin, as an antirheumatic gold compound, suppresses LPS-induced homodimerization of TLR4. Biochem Biophys Res Commun. 2006;350:866-71.

60. Reddy S, Damle NK, Venkatesan AM, Thompson SK, Rao N, Smith RA, Gupta S. Abstract 792: ASN002: a novel dual SYKJJAK inhibitor with strong antitumor activity. Cancer Res. 2015;75:792.

61. Boyle JN, Kim CR, Guo H, Bell T, Huang S, Li CJ, Liu Y, Zhang H, Wang J, Zhang V, et al. CUDC-907: an oral HDAC/PI3K dual inhibitor with strong preclinical efficacy in MCL model. Blood. 2016;128:4183.

62. Aoki T, Shimada K, Sakamoto A, Sugimoto K, Morishita T, Kojima Y, Shimada S, Kato S, Iriyama C, Kuno S, et al. Emetine elicits apoptosis of intractable Bcell lymphoma cells with MYC rearrangement through inhibition of glycolytic metabolism. Oncotarget. 2017;8:13085-98.

63. Smith BD, Levis M, Beran M, Giles F, Kantarijan H, Berg K, Murphy KM, Dauses T, Allebach J, Small D. Single-agent CEP-701, a novel FLT3 inhibitor, shows biologic and clinical activity in patients with relapsed or refractory acute myeloid leukemia. Blood. 2004;103:3669-76.

64. Ham M, Moss AC. Mesalamine in the treatment and maintenance of remission of ulcerative colitis. Expert Rev Clin Pharmacol. 2012;5:113-23.

65. Zak Z, Gelebart P, Lai R. Fenofibrate induces effective apoptosis in mantle cell lymphoma by inhibiting the TNFalpha/NF-kappaB signaling axis. Leukemia. 2010;24:1476-86

66. Kaufmann H, Raderer M, Wohrer S, Puspok A, Bankier A, Zielinski C, Chott A, Drach J. Antitumor activity of rituximab plus thalidomide in patients with relapsed/refractory mantle cell lymphoma. Blood. 2004;104:2269-71.

67. Ruan J, Martin P, Shah B, Schuster SJ, Smith SM, Furman RR, Christos P, Rodriguez A, Svoboda J, Lewis J, et al. Lenalidomide plus rituximab as initial treatment for mantle-cell lymphoma. N Engl J Med. 2015;373:1835-44.

\section{Ready to submit your research? Choose BMC and benefit from:}

- fast, convenient online submission

- thorough peer review by experienced researchers in your field

- rapid publication on acceptance

- support for research data, including large and complex data types

- gold Open Access which fosters wider collaboration and increased citations

- maximum visibility for your research: over $100 \mathrm{M}$ website views per year

At BMC, research is always in progress.

Learn more biomedcentral.com/submissions 